\title{
ІСТОРІЯ МИКОЛАЇВСЬКОЇ КАТОРЖНОЇ ТЮРМИ (1907-1920 РР.)
}

Анотація: У статті досліджується створення та функціонування протягом 1907-1920 рр. Миколаївської каторжної тюрми № 2

Встановлено, що щорічно через в'язнищю проходило від 400 до 600 осіб (більша частина яких була ув'язнена за політичними мотивами), серед яких зустрічалися й відомі революиіонери та герої громадянської війни: Григорій Котовський, Михайло Фрунзе, Афанасій Матюшенко.

Досліджено побут ув'язнених і виявлено, що на території тюрми функціонувала школа, храм і бібліотека. Діяли майстерні, зокрема: столярна, кравецька, взуттєва, слюсарна, палітурна та миловарна, обладнані всіма необхідними верстатами.

Проіснувала Миколаївська каторжна в'язниия до 1920 р., поки не була переведена радянською владою у категорію «загальної» тюрми.

Ключові слова: каторжна тюрма, пенітениіарна система, Миколаївський піклувальний про тюрми комітет, Російська імперія, Миколаїв, Григорій Котовський, Михайло Фрунзе, Афанасій Матюшенко

Каторга - складне та суперечливе історичне явище, яке, втім, відіграло досить важливу роль у житті багатьох громадян Російської імперії. На жаль, історія українських земель у багатьох аспектах пов'язана з покараннями позбавлення волі - відправлення у заслання, або ж на каторжні роботи; ув'язненням у монастир, острог, фортецю, тюрму тощо. Буржуазні реформи кінця XIX - початку XX ст. спричинили кардинальні зміни у системі покарань Російської імперії. Однак, на території держави ще продовжували існувати такі архаїчні види покарань, як наприклад, посилання на каторжні роботи, які перестали відповідати новим реаліям тогочасного суспільства. Існували каторжні тюрми й на території українських губерній, у тому числі і в Миколаєві. Дана проблема є особливо актуальною в наш час у зв'язку зі становленням у сучасній Україні громадянського суспільства та правової держави, а також гуманізацією системи покарання.

Актуалізує зазначене питання ще й те, що у сучасній українській історіографії тема функціонування каторжних тюрем на території України майже не досліджена і до сьогодні відсутні узагальнюючі роботи з цієї проблематики. Існують лише окремі праці авторів, які загально, або ж опосередковано, торкаються зазначеного питання та низка статей краєзнавчого характеру. Серед них можна виділити публіцистичні праці С. Гаврилова й Ю. Любарова ${ }^{2}$ та Н.Христової. у 2019 р. вийшла друком стаття Лариси Левченко

\footnotetext{
${ }^{1}$ Біліченко Лідія Сергіївна - аспірант кафедри історії Чорноморського національного університету імені Петра Могили (Миколаїв, Україна); ORCID: https://orcid.org/0000-0001-5547-9248; e-mail: bilichenko.lidia@gmail.com

${ }^{2}$ Гаврилов С., Любаров Ю. Николаев - 220 лет: очерки истории жизни города и горожан. Николаев, 2009. 208 с.

${ }^{3}$ Христова Н. Тюремный маршрут: гауптвахта, острог, «бухтеевка», каторжная тюрьма // Вечерний Николаев.
} 
«Миколаївський піклувальний про тюрми комітет як орган управління тюремним господарством та опіки над в'язнями», де на основі архівних джерел розкривається i діяльність миколаївської каторжної тюрми №2. Наукова розвідка містить дуже цінну інформацію про побут ув'язнених та їх роботу в тюремних майстернях.

Разом 3 тим, існує цілий пласт робіт російських науковців, які багато уваги приділяють місцю та ролі каторги в історії російської держави. Серед них можна виділити праці А. Філатова ${ }^{5}$, М. Гернета ${ }^{6}$, Д. Дриля ${ }^{7}$ С. Ковалика ${ }^{8}$, В. Андрєєва ${ }^{9}$, П. Казаряна ${ }^{10}$.

Виходячи 3 вищесказаного, автор поставила собі за мету на основі новітньої літератури та наративних джерелах (спогадах колишніх в'язнів), дослідити діяльність Миколаївської каторжної тюрми протягом 1907-1920 рр.

На початку XX ст. тюремна інфраструктура Херсонської губернії відчувала значне навантаження. Ріст чисельності населення на околицях держави та зростаючі показники кримінальної статистики у південних регіонах міста породили гостру нестачу пенітенціарних закладів. Камери старих тюрем і пересильних дільниць були забиті вкрай. Тіснота, антисанітарія та погане харчування призводили до високої смертності злочинців. Тимчасові слідчі дільниці не могли вмістити зростаючу кількість підсудних. Тому часто люди, вина яких не була ще доведена судом, утримувалися у переповнених камерах i помирали у тюремних лікарнях від «професійних» хвороб.

Саме $з$ вищесказаних причин у 1907 р. Головне управління тюрем при МВС Російської імперії у відповідь на доповідну записку Миколаївського градоначальника контр-адмірала Василя Максимовича Зацарьонного видає спеціальний наказ про заснування у Миколаєві каторжної тюрми.

Поява нової «пересилки» у просторій будівлі колишнього Штурманського училища розвантажило на деякий час поліцейські околищі Херсона, Одеси та Миколаєва. На вікнах колишніх навчальних класів були встановлені грати, а територія Лагерного поля огороджена глухою стіною11. Основні будівництва завершилися через два роки, однак будівельні роботи тут тривали аж до 1916 р. під керівництвом архітектора Костянтина Петровича де ла Валетта ${ }^{12}$.

Начальником миколаївської каторжної тюрми був обраний Ф.Д. Колченко.

2020. N 46. С. 6-7.

${ }^{4}$ Левченко Л. Миколаївський піклувальний про тюрми комітет як орган управління тюремним господарством та опіки над в'язнями // Вісник Пенітенціарної асоціації України. 2019. № 3. С. 44-58.

${ }_{5}^{5}$ Филатов А.В. Строительство и размещение каторжных тюрем Восточной Сибири в конце XIX - начале XX века // История Сибири, 1583-2006. Проблемы и перспетивы: Сборник материалов региональной молодежной научной конф. Новосибирск, 2006. С. 132-139.

${ }^{6}$ Гернет М.Н. История царской тюрьмы. В пяти томах. Изд. 3-е. Т. 2. 1825-1870. Москва: Государственное издательство юридической литературы, 1961. 582 с.

7 Дриль Д.А. Ссылка во Франции и России. Санкт-Петербург: Тип. Пантелеева, 1899. 174 с.

${ }^{8}$ Ковалик С. Революционеры-народники в каторге и ссылке. (По личным воспоминаниям) // Каторга и ссылка. 1924. № 4 . С. 139-171.

${ }^{9}$ Андреев В.М. Просветительская деятельность ссыльных народников в Сибири (70-90 гг. ХІХ в) / Ссыльные революционеры в Сибири. Иркутск: Изд. Иркут. ун. им. А.А. Жданова. 1973. Вып. І. С. 26-51.

${ }^{10}$ Казарян П.Л. Верхоянская политическая ссылка. 1861-1903 гг. Якутск: ЯНЦ СО АН СССР. 1989. 176 с.

${ }^{11}$... C. 122.

${ }^{12}$ Христова Н. Тюремный маршрут... С. 6. 
Заступником начальника тюрми призначено В.А. Вейнберга, а помічникими П.Є. Тимновського та І.А. Трегубова ${ }^{13}$.

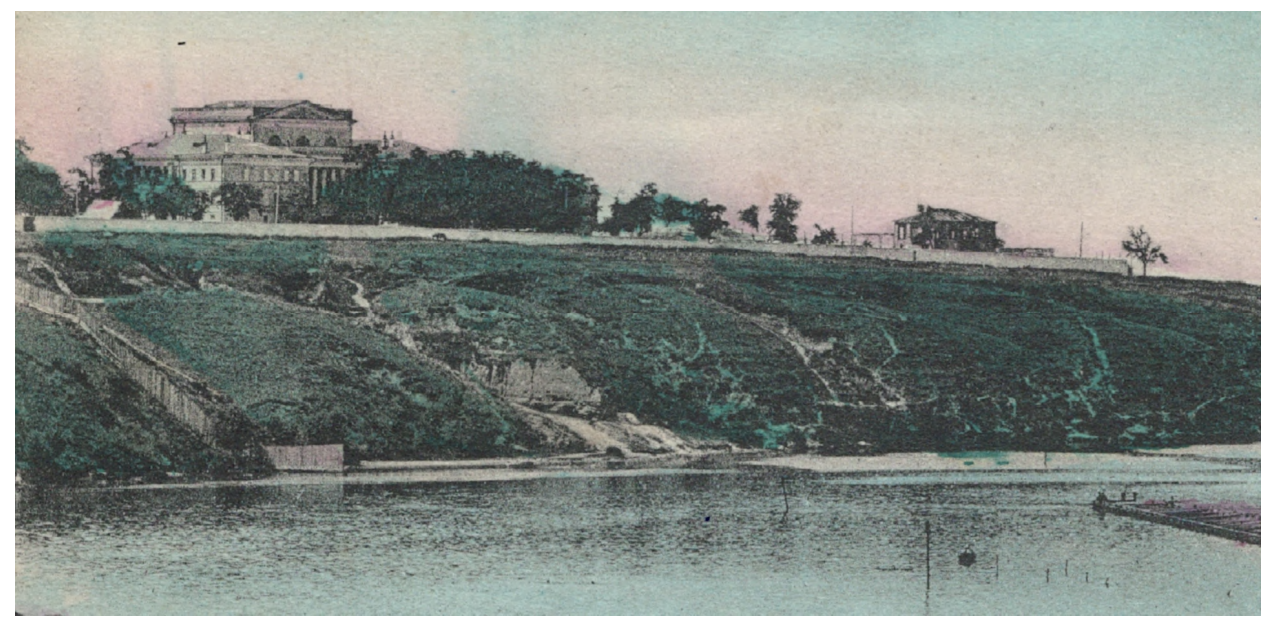

Рис. 1. Будівля Штурманського училища на початку XX ст. (майбутня Каторжна тюрма № 2) Фрагмент листівки початку XX ст. (видавці брати Я. і М. Заславські у Миколаєві) $)^{14}$

Будівля (рис. 1) по санітарним нормам тюремного управління Російської імперії, була спочатку розрахована на одночасне утримування 750 осіб. Однак, ці норми до революції ніколи не виконувались. Кількість затриманих коливалася від 1000 до 1400 осіб ${ }^{15}$. Встановлене нове обладнання значно полегшувало роботу обслуговуючого персоналу: тут були кухня з чотирма мідними котлами, три печі в пекарні, парова пральня 3 механічними пральними машинами, у дворі працював млин ${ }^{16}$.

Адміністрація тюрми намагалася ізолювати криміналітет від політичних в'язнів у різних камерах з міркувань безпеки, побоюючись, що політичні в'язні внесуть елемент організованості в егоїстичний злочинний осередок і направлять кримінальну винахідливість злочинців на реалізацію планів бунта та втеч ${ }^{17}$.

Щорічно через в'язницю проходило від 400 до 600 осіб каторжних. Чверть 3 них були представники національних меншин - татари, абхазці, чеченці, вірмени. Багато «іновірців» сиділи за «вендету» - родову помсту. В'язнів умовно можна було розділити на дві групи. Перша - це «смертники», засуджені за вбивство, або збройний напад, грабіжники, матроси та солдати повсталих частин. Друга група - «малосрочники», які одержували від 4 до 8 років: члени РСДРП, фальшивомонетники, грабіжники ${ }^{18}$.

Історія тюрми містить епізоди, в яких діючими особами виступають відомі

\footnotetext{
${ }^{13}$ Адресная и справочная книга всего Николаева на 1912 год / изд. Д.А. Белый. Николаев: Типография «Трудовой Газеты», 1911. С. 58.

${ }^{14}$ Редакція вдячна миколаївському краєзнавцю Юрію Любарову за надану світлину. - Прим. ред.

${ }^{15}$ Гаврилов С., Любаров Ю. Николаев - 220 лет... С. 122.

${ }^{16}$ Христова Н. Тюремный маршрут... С. 6.

${ }^{17}$ Гаврилов С., Любаров Ю. Николаев - 220 лет... С. 123.

${ }^{18}$ Христова Н. Тюремный маршрут... С. 6.
} 
революціонери та герої громадянської війни ${ }^{19}$. Зокрема, тут сидів легендарний Григорій Котовський. У 1907 р. Котовського за грабежі засудили до 12 років каторги, і свій довгий шлях по тюрмах Російської імперії він почав у Миколаєві. За переказами радянського часу (оскільки дана інформація не підтверджена документально) майбутній комдив сидів в одиночці, його побоювалося тюремне начальство та кримінальні авторитети, що дало йому змогу скасувати так званий податок «на камеру» на користь тюремної кримінальної верхівки ${ }^{20}$.

У березні 1908 р. начальник Миколаївського охоронного відділення повідомляв, що надійшли агентурні відомості, суть яких була у наступному: ув'язнені готували бунт і втечу. На чолі змовників стояли арештанти: «Фаня» - Опанас Таран, «Тарс» - Вільгельм Мессерле, Андрій Луцкан та «отаман розбійницької шайки» Котовський ${ }^{21}$. Однак, змовників охоронців вдалося вчасно викрити. У 1910 р. Котовського відправили з Миколаєва до Смоленської пересильної тюрми й далі до Сибіру, на каторжні роботи у Нерчинські рудники.

У серпні 1907 р. миколаївська поліція затримала одного з найбезпечніших злочинців свого часу - організатора бунту на броненосці «Потьомкін» Афанасія Матюшенка, який чекав вирішення своєї долі у миколаївській каторжній тюрмі ${ }^{22}$. Восени того ж року, на спеціально надісланому міноносці під посиленою охороною (7 офіцерів і 60 матросів), у кайданах його перевезли до Севастополя. 17 жовтня 1907 р. його було засуджено до страти через повішення. Вирок був виконаний зранку 20 жовтня 1907 р. у дворі Севастопольської тюрми.

Побував у миколаївській каторжній тюрмі й Михайло Васильович Фрунзе революціонер, майбутній «радянський державний діяч і воєначальник Червоної армії» часів громадянського протистояння 1917-1921 pp. Він випадково потрапив на одеському морвокзалі у планову поліцейську облаву та був відправлений до камери миколаївської тюрми. Революціонера заарештували за загальним указом Міністра внутрішніх справ Російської імперії, направленому проти всієї соціал-демократичної партії більшовиків.

у 1912 р. член більшовицької фракції III Державної думи Петро Бабаєв виступив 3 обвинувачувальною промовою з приводу розстрілу робочих на Ленських золотих копальнях і закликав з думської трибуни до повалення самодержавства у Росії. Через двадцять хвилин вся фракція за навмисну провокацію антиконституційних дій була позбавлена депутатського імунітету та заарештована. На наступний день усі функціонери середньої ланки партії більшовиків на периферії були затримані поліцією як політичні терористи та без пред'явлення обвинувачуваного вироку розміщені під варту. Під роздачу потрапив і Фрунзе ${ }^{23}$. Спочатку вирок для нього був суворий - страта. Але невдовзі вона була замінена на 10 років каторжних робіт.

Потрапивши до Миколаєва, М.Фрунзе написав листа до начальника каторжної тюрми 3 проханням переправити йому з Володимира його особисті речі, які він там

\footnotetext{
${ }^{19}$ Гаврилов С., Любаров Ю. Николаев - 220 лет... С. 123.

${ }^{20}$ Кот наводил порядок в виколаевской http://nikolaevnews.com.ua/other/2020/06/23/221557.html

${ }^{21}$ Держархів Миколаївської області. Ф. П-1817 «Миколаївський окружний відділ 3 вивчення історії Комуністичної партії і Жовтневої революції Істпарту ЦК КП(б)У». Оп. 2. Спр. 91. Арк. 4.

${ }^{22}$ На захисті людини. Міліщія Миколаївщини: історія та сьогодення: у 2 т. Миколаїв: Іліон, 2008. С. 33.

${ }^{23}$ Гаврилов С., Любаров Ю. Николаев - 220 лет... С. 123.
} 
залишив. У їх числі - ковдра байкова, піджаки ватний і суконний, брюки, сорочка, кальсони, ремінь, калоші, простирадло, рушники, шкарпетки, панчохи, шапка, чоботи шкіряні, а також ручка від чайника. До того ж він просив повернути йому 30 руб., дві фотографії, 77 книжок різного змісту та один зошит. Подібні речі були повернуті його колезі - Герасиму Вареласу, з яким він прибув під конвоєм до Миколаєва.

Утримувався на миколаївській каторзі й один із відомих бойовиків Миколаївської групи анархо-комуністів на теренах півдня імперії шістнадцятирічний Павло Коротков, котрий замахнувся на життя околоточного наглядача ${ }^{24}$. Згодом, після декількох арештів і втеч 3 тюрем Миколаєва й Одеси, приєднався до до бойової анархістської дружини «Новый мир». У грудні 1907 р. його було заарештовано та засуджено до смертної кари через повішання. Страчений в Одеській в'язниці 10 січня 1908 р. ${ }^{25}$

Були в історії каторжної в'язниці і ганебні «плями», зокрема епізоди нерегламентованої розправи над в'язнями. У 1907 р. «політичні арештанти» почали вести себе свавільно по відношенню до караулу. Співали революційні пісні, називали вартових «холопами» та «рабами» й погрожували розправою, коли прийде «царство правди». Один вартовий не витримав та застрелив одного арештанта.

Інший випадок трапився 28 липня 1908 р., коли у каторжній тюрмі вели ув'язнених на роботу в столярну майстерню. Арештант Федоров на першому поверсі з вікна почав робити руками якісь знаки іншому в'язню, який знаходився на той момент на вулиці. На трикратне попередження наглядачів припинити ці дії, Федоров не звернув уваги та був застрелений ${ }^{26}$.

Досить цінну інформацію про перебування в миколаївській тюрмі у своїх спогадах залишив Лев Бронштейн (він же «демон» революції - Лев Троцький). Зокрема він згадував:

«...Миколаївська в'язниця зовсім не була пристосована для політичних, та ще й у такій кількості. Стояли січневі морози. На ніч нам клали на підлогу соломенник, а о шостій годині ранку виносили його. Підніматися й одягатися було найнестерпнішим. Арештантську юшку давали раз на день, в обід. Пайок житнього хліба з сіллю служив мені сніданком і вечерею. Я вів з собою довгі діалоги про те, чи маю я право збільшити ранкову порцію за рахунок вечірньої. Ранкові доводи здавалися ввечері безглуздими та злочинними. За вечерею я ненавидів того, який снідав. У мене не було зміни білизни. Три місяці я носив одну і ту ж пару. У мене не було мила. Тюремні паразити їли мене заживо.

Я давав собі урок: пройти по діагоналі тисячу сто одинадцять кроків. Мені йшов дев'ятнадцятий рік. Я відкушував шматочок тюремного хліба, ходив по діагоналі і складав вірші. Вельми посередньої якості, вірші ці пізніше набули неабиякої популярності. Вони передруковуються у пісенниках і зараз. Але іноді мене гризла жорстока туга самотності. Тоді я перебільшено твердо відраховував стоптаними підметками тисячу сто одинадцять кроків.

До кінця третього місяця, коли тюремний хліб, мішок, набитий соломою, і воші стали для мене непорушними елементами життя, як день і ніч, наглядачі ввечері внесли до мене гору предметів з іншого, фантастичного світу: свіжу білизну, ковдру, подушку, білий хліб, чай, цукор, шинку, консерви, апельсини, яблука, так, великі яскраво забарвлені апельсини... і зараз, через 31 рік, я не без хвилювання перераховую ці чудові предмети і

\footnotetext{
${ }^{24}$ На захисті людини. Міліція Миколаївщини... С. 33.

${ }^{25}$ Савченко В.А. Анархістський рух в Одесі (1903-1916 рр.). Одеса: Печатный дом, 2014. С. 141.

${ }^{26}$ Гаврилов С. Старая тюрьма // Наш голос. 2010. № 36 (250). 8-14 сентября. С. 6.
} 
викриваю себе в тому, що упустив баночку варення, мило і гребінець. «Це вам мати доставила», - сказав мені помічник. І як не погано я тоді читав у людських душах, але по тону його зрозумів відразу, що він отримав хабар...» ${ }^{27}$.

у свою чергу, В.Л.Арендт - колишній в'язень миколаївської каторжної тюрми згадував про те, що «всі камери були світлі та чисті, але у камерах сиділа велика кількість людей, яка набагато перевищувала норму. Дошкуляли зайвою строгістю. У ватерклозети водили рідко, по чотири чоловіки. У камерах стояв нестерпний сморід» ${ }^{28}$.

До слів Л. Троцького й В. Арендта хочеться додати, що ув'язнені постійно перебували в кайданах, які навіть у лазні знімати заборонялося. Сама ж лазня з холодною водою була доступна лише двічі на місяць, рушник міняли двічі на рік, про зміну постільної білизни й зовсім не йшлося. На харчування ув'язненим відводили від 6 до 10 копійок на день. Вони отримували пресований чай, два фунти хліба, 2-3 ложки каші, а вранці - гарячу воду ${ }^{29}$.

Однак, не дивлячись на це, умови в миколаївській каторжній тюрмі були не найгірші. Так, у своїх мемуарах колишній в'язень Костянтин Галкін писав: «На початку XX ст. у всіх босяків та каторжного люду створилося міцне негативне відношення до місцевих тюрем... Всі вони утримували від в'язнів невтішні прізвиська. Херсонська пересилка йменувалася «голодухою», Одеська - «кнутовою», Єлисаветградська «чугунною» і лише миколаївська пересилка була «царським прощенням». Потрапити на миколаївську пересилку було великою вдачею. Миколаївська тюрма була мрією...» ${ }^{30}$.

«М'які умови» миколаївської каторжної тюрми сформувалися у загальному напрямку гуманізації системи виконання покарань Російської імперії. 31903 року були скасовані приковування до тачанки, гоління половини голови та побиття трихвостним батогом. Однак, в арсеналі тюремних наглядачів залишилися принизливе пороття різками на покарання карцером з видачею гарячої їжі через три дні на четвертий.

Тюремні установи всієї імперії вимагали благодійні внески зі сторони громадянського суспільства. Це завдання передбачалося вирішити шляхом діяльності в тюрмі храмів, бібліотек і шкіл.

В арештантському відділі миколаївської каторжної тюрми існувала СвятоОлексіївська церква, яка після перетворення колишнього морського острога залишилася на території тюрми та була викуплена тюремним відомством за 2500 руб. У штаті приходу перебував священник і псаломщик, а з 1912 р. старостою церкви став Лука Донський. Слід відзначити, що будівля храму була віддалена від тюремних корпусів, аби службу могло відвідувати й місцеве населення.

У програмі діяльності тюремного управління по моральному виправленню в'язнів нагально стояло питання про створення тюремної бібліотеки. Чиновники звернулися до Комітету грамотності з проханням про висилку каталогу книг. У відповідь отримали списки iз сотні найменувань, в яких окрім літератури релігійного змісту були твори Григоровича, Толстого, Гоголя, Тютчева. Станом, на 1911 р. у бібліотеці каторжної тюрми нараховувалося

\footnotetext{
${ }^{27}$ Троцкий Л. Моя жизнь. Опыт автобиографии. Москва: «Панорама», 1991. С. 123.

${ }^{28}$ Гаврилов С. Старая тюрьма... С. 7.

${ }^{29}$ «Чи є життя за гратами?» // Урядовий кур'єр. 2013. 29 березня. С. 12.

${ }^{30}$ Галкін К. По царським в'язницях. 1905-1907. Харків: Державне видавництво України, 1927. С. 39.
} 
вже 775 одиниць зберігання.

Діяла у каторжній тюрмі і школа. В ній вчили Закону Божому та російській мові, а по неділям священник проводив загальні читання та бесіди. Відвідували школу 35-40 осіб ${ }^{31}$.

Функціонували у каторжній тюрмі і майстерні. Так, за даними миколаївської дослідниці Л.Левченко, станом на 1910-1911 pр. у Миколаївській каторжній тюрмі працювали столярна, кравецька, взуттєва, слюсарна, палітурна та миловарна майстерні, обладнані всіма необхідними верстатами. У виправному арештантському відділенні працювали столярна, ткацька, швецька, кравецька, оббивочна, палітурна, картонажна, ковальська, слюсарна, корзинна майстерні. На виконувані арештантами за замовленнями роботи були чітко визначені ціни. Наприклад, виготовлення шафи для одягу 3 вільхи коштувало 5 руб., з ясеню - 6 руб., полірованого комоду з вільхи - 4 руб., з ясеню - 6 руб., сундука - 4 руб. Пошиття лакованих чобіт оцінювалося в 1 руб. 20 коп., чоловічих черевиків - від 50 до 65 коп., жіночих - від 50 до 70 коп., чоловічих туфель - від 30 до 60 коп., жіночих - від 40 до 75 коп., дитячих чобіт - від 25 до 70 коп., костюму звичайного - 5 руб., модного пальто - 8 руб., простого - 5 руб., дитячого пальто - 3 руб. Оббивка плюшем дивану середньої величини коштувала 3 руб., матрацу двоспального пружинного - 60 коп., кушетки - 1 руб. 20 коп. Книжку сап'янову із золотим тисненням оправляли за ціну від 15 до 40 коп., теки коленкорові виготовляли залежно від розміру за ціну від 20 до 50 коп., на більш витончені палітурні роботи встановлювалися договірні ціни ${ }^{32}$.

Поряд 3 більш традиційними майстернями працювали художня, годинна, миловарна, малярська. Ув'язнені шили обмундирування для воїнів 58-го Празького полку та робочий одяг для працівників суднобудівного заводу «Наваль». Наділені талантами писали картини.

у 1911 р. в Царському Селі відбулася реміснича виставка, на якій були представлені експонати, виготовлені ув'язненими миколаївської в'язниці №2. В експозиції виявилися портрет царської сімї̈, сітки гарусна та вовняна для покриття коней при катанні на санях, стільці ясеневі столові, вулик для бджіл, гамак, туфлі жіночі і чоловічі шеврові та лакованіз .

у 1911 р. Миколаївська тюремна інспекція з метою збільшення тюремного заробітку запропонувала відкрити при Миколаївській каторжній в'язниці друкарню. Ця пропозиція була схвалена вищим тюремним керівництвом, оскільки вважалося, що підприємство зможе щорічно приймати замовлень на 130 тис. руб. У друкарні виготовлялися бланки, афіші, рекламні проспекти, етикетки, наукові брошури, звіти різних відомств, адрескалендарі, прейскуранти тощо. Крім майстерень, в'язні, переважно арештантського відділення та міської тюрми, працювали на різних зовнішніх роботах у місті, в порту, на залізниці ${ }^{34}$.

У 1909 р. був виданий закон про дострокове звільнення. В ньому йшлося про необхідність створення громадських організацій, які б займалися опікунством над звільненими з міст ув'язнення. Результатом цього закону стало створення по всім губерніям благодійної організації «Патронат». Так, миколаївська благодійна спільнота за шість місяців

\footnotetext{
${ }^{31}$ Гаврилов С. Старая тюрьма... С. 7.

32 Левченко Л. Миколаївський піклувальний про тюрми комітет... С. 51.

${ }^{33}$ Христова Н. Тюремный маршрут... С. 6.

34 Левченко Л. Миколаївський піклувальний про тюрми комітет... С. 51.
} 
1910 р. зібрала 450 руб. 19 коп. Членські внески від 58 членів складали 177 руб., приватні пожертвування - 73 руб. 19 коп., допомога від головного управління - 200 руб. Із цих грошей 135 руб. 4 коп. були роздані на фінансову допомогу від 5 до 30 руб. ${ }^{35}$

2 травня 1912 р. каторжній в'язниці довелося пережити вибух порохового льоху. Він приніс численні руйнування, які довелося відновлювати також за рахунок громадських фондів ${ }^{36}$.

у 1915 р. у миколаївській каторжній в'язниці відбуваються важливі кадрові перестановки. Новим начальником тюрми стає титулярний радник Олексій Олександрович Завалишин. Кадровий склад в'язниці виглядав наступним чином (Табл. 1):

Таблиця 1

Кадровий склад Миколаївської каторжної тюрми № $2^{37}$

\begin{tabular}{|l|c|}
\hline \multicolumn{1}{|c|}{ Прізвище } & Посада \\
\hline Вейнберг Володимир Альбертович & Старший помічник \\
\hline Крижанівський Іван Іванович & Помічник \\
\hline Ковальський Олексій Семенович & Помічник \\
\hline Дружинін Олексій Анемподович & Помічник \\
\hline Камінський Клемент Матвійович & Помічник \\
\hline Мельников Олександр Олександрович & Помічник \\
\hline Ільїнський Олександр Іванович & Лікар \\
\hline Недригайлов Анатолій Петрович & Священник \\
\hline Покрась Петро & Фельдшер \\
\hline Бафталовськи Іван Феофанович & Фельдшер \\
\hline Мощак Василій Єфимович & Фельдшер \\
\hline
\end{tabular}

До виконання тюремних завдань залучалися губернські комітети Піклувального по тюрмам комітету. Серед директорів миколаївського комітету в 1915 р. ми знаходимо промисловців А.Ф. і Л.Ф. Донських, А.Н. Лазарева, Т.А. Баздирева, А.Ф. Чуткова, директора правління кредитної спілки Сиротинського, мирового суддю та директора міського музею C.I. Гайдученка. Кошти комітету складалися із членських внесків директорів, державного казначейства та добровільних пожертвувань. У розпорядження комітетів надходили усі суми, які відпускалися на продовольства для арештантів, на їх одяг, тюремну лікарню й утримання тюремного персоналу ${ }^{38}$.

Функціонувала каторжна в'язниця і в період революційних подій 1917-1920-х рр. У лютому 1917 р., коли по країні прокотилася хвиля Лютневої революції, миколаївські революціонери з червоними прапорами та святковими вигуками рушили до тюремних

\footnotetext{
${ }^{35}$ Гаврилов С. Старая тюрьма... С. 7.

${ }^{36}$ Христова Н. Тюремный маршрут... С. 6.

${ }^{37}$ Адрес-календарь Николаевского градоначальства на 1915 год / Канцелярия Николаевского градоначальства. Николаев : Электрич. типолитография бр. Л. и И. Белолипских, 1914. С. 114-115.

${ }^{38}$ Гаврилов С. Старая тюрьма... С. 7.
} 
воріт звільняти політв'язнів. Заодно свободу отримав і кримінальний елемент ${ }^{39}$.

17 березня 1918 р. знов відбулася зміна влади - у Миколаїв вступили німецькі військові частини. Сучасник подій, німецький офіцер Вальтер Фест розповів як ув'язнені миколаївської каторжної в'язниці, скориставшись ситуацією, коли німецькі війська вступили в бій з наступаючою армією Симона Петлюра, зламали двері та замки камер.

«Вони розбили вікна, шафи, столи, розірвали на шматки всі знайдені у кабінетах документи та папери. Понад 400 ув'язнених зібралися у дворі каторжної в'язниці, а з вулиці у цей час сотні городян намагалися проникнути до будівлі. Жахливий крик і шум лунали на вулиці. Деяким німецьким наглядачам вдалося викликати 8-ю роту 415-го піхотного полку і 3 їх допомогою зупинити остаточне розграбування каторжної в'язниці.

Плачевно виглядали вулиці на наступний ранок. Автоматична зброя, самохідні гармати, револьвери, автомобілі та коні були залишені військами гетьмана прямо на вулицях міста. Активізувалися сумнівні елементи суспільства, для котрих велике значення мала легка нажива. Скрізь панував безлад» ${ }^{40}$.

Однак, випробування для тюрми цим не завершилися. У 1918 р. загін анархістів брав штурмом тюрму, намагаючись звільнити своїх колег. При штурмі анархісти знищили тюремні архіви, що призвело до втрати більшої частини архівних документів й імена людей, які відвідали стіни миколаївської каторжної тюрми № 2, майже не збереглися ${ }^{41}$.

Таким чином, дослідивши історію Миколаївської каторжної тюрми упродовж 19071920 рр. можна зробити такі висновки. По-перше, у в'язниці утримувались як політичні, так i кримінальні в'язні. Серед них зустрічалися революціонери та майбутні герої громадянської війни: Афанасій Матюшенко, Григорій Котовський, Михайло Фрунзе. Подруге, умови утримання в'язнів у каторжній тюрмі були далекими від ідеалу: камери тюрми були тісними та переповненими; не вистачало їжі; часто арештанти страждали від свавілля наглядачів. Однак, не дивлячись на це, умови в миколаївській каторжній тюрмі у порівнянні з іншими тюрмами Російської імперії були не найгірші. Зокрема, у в'язниці працювали столярна, кравецька, взуттєва, слюсарна, палітурна та миловарна майстерні, обладнані всіма необхідними верстатами. Поряд 3 більш традиційними майстернями працювали художня, годинна, миловарна, малярська. При тюрмі функціонували школа, бібліотека, Свято-Олексіївська церква та друкарня. Активно залучалися у підтримку Миколаївської каторжної тюрми й губернські комітети. У розпорядження комітетів поступали усі суми, які відпускалися на продовольства для арештантів, на їх одяг, тюремні лікарні та утримання тюремного персоналу.

Говорячи про місце і роль Миколаївської каторжної тюрми у системі пенітенціарних установ Російської імперії початку XX ст., необхідно зробити висновок, що Миколаївська каторга виступала в ролі одного з важливих пенітенціарних закладів країни, яка реалізувала найбільш затребуваний вид кримінального покарання. Поєднання різноманітних методів при реалізації кримінального покарання у вигляді каторги, визначили специфічний,

\footnotetext{
${ }^{39}$ Христова Н. Указ. раб. С. 6.

${ }^{40}$ Фест В. Николаев: последний форпост немецких войск на Черном море. Николаев: ПГО «Центр виробничої практики інвалідів АТО «ЛІТОПИС», 2016. С. 72-73

${ }^{41}$ Юбилей тюрьмы комдива Фрунзе. URL: https://www.segodnya.ua/regions/odessa/jubilej-tjurmy-komdivafrunze-84001.html
} 
подвійний статус Миколаївської каторжної тюрми як інструменту каральної політики держави за допомогою позбавлення волі та віддалення від місць проживання осіб, які вчинили тяжкі кримінальні злочини. Подібна неоднозначність дозволяє визначити Миколаївську каторжну тюрму і як один 3 механізмів реалізації регіональної пенітенціарної політики Російської імперії на території півдня України.

\section{Lidiia Bilichenko}

\section{History of Mykolaiv Captive Prison (1907-1920)}

Abstract: The article examines the creation and functioning of the Mykolayiv Convict Prison during 1907-1920. It is estimated that between 400 and 600 people passed through the prison each year. A quarter of them were representatives of national minorities - Tatars, Abkhazians, Chechens, Armenians. Many «infidels» sat for «vendetta» - tribal revenge. Prisoners could be divided into two groups. The first is «suicide bombers» convicted of murder or armed assault, robbers, sailors and soldiers of insurgent units. The second group - «shortterm», who received from 4 to 8 years: members of revolutionary parties, counterfeiters, robbers. Among the prisoners were well-known revolutionaries and heroes of the Civil War: Hryhoriy Kotovsky, Mykhailo Frunze, Athanasius Matyushenko.

The life of the prisoners was investigated and it was found that there was a school, a temple and a library on the territory of the prison. There were also workshops, in particular: carpentry, tailoring, shoe, metalwork, binding and soap workshops, equipped with all necessary machines. Along with more traditional workshops worked art, watch, soap, painting. Prisoners sewed uniforms for soldiers of the $58^{\text {th }}$ Prague Regiment, work clothes for employees of the Naval shipyard.

The penal colony lasted until 1920, when it was transferred by the Soviet authorities to the category of «general» prison.

Keywords: convict prison, penitentiary system, Mykolayiv Prison Trustees Committee, Russian Empire, Mykolayiv, Hryhoriy Kotovsky, Mykhailo Frunze, Athanasius Matyushenko 